\title{
PRE-WAR INDONESIAN NATIONALISM AND THE PERANAKAN CHINESE
}

\section{Leo Suryadinata}

\begin{abstract}
The beginnings of an Indonesian nationalist movement led by Western educated Indonesian elites and aiming at the end of Dutch colonial rule are conventionally dated to the year 1908 when the Budi Utomo was established. However, the concept of an Indonesian Nation (Bangsa Indonesia) did not emerge in that year. In fact this concept was developed very gradually in various political parties which grew up after Budi Utomo and was only crystalized after the Communist uprisings of 1926-27. Harry Benda and Ruth McVey $^{1}$ have categorized the rise of Indonesian nationalism into a proto-nationalist phase prior to the uprisings, and a phase of nationalism proper which began after their collapse. This short article attempts to examine the political position of the peranakan Chinese $^{2}$ in these two historical phases and to throw light on their relationship with indigenous Indonesian elites before the Second World War.
\end{abstract}

The Peranakan Chinese and Indonesian Proto-Nationa1ism

The Tiong Hoa Hwee Koan, the first Pan-Chinese organization, was formed in $1900,{ }^{3}$ i.e., before the formal appearance of Indonesian proto-nationalism. As early as the turn of the twentieth century the Chinese began consciously to think of themselves as part of the Chinese nation (Bangsa Tionghoa), ${ }^{4}$ indicating that they saw themselves

1. For their arguments see the introductory essay in, Harry J. Benda and Ruth T. McVey, The Communist Uprisings of 1926-1927 in Indonesia: Key Documents (Ithaca: Corne11 Modern Indonesia Project, 1960).

2. Peranakan Chinese are Chinese born in Indonesia (often of mixed Chinese and Indonesian descent), and they are to some degree assimilated to local culture. Totok Chinese, by contrast, are recent immigrants, and they remain culturally and linguistically oriented toward China.

3. For a fuller account on the emergence of the Pan-Chinese movement, see Lea E. Williams, Overseas Chinese Nationalism: The Genesis of the Pan-Chinese Movement in Indonesia, 1900-1916 (Glencoe: Free Press, 1960).

4. Tionghoa was used to refer to the Chinese in the Indies after the rise of the Pan-Chinese movement; the term Tjina, which had been used to refer to China and the Chinese since the seventeenth century, was how considered to be derogatory by the peranakan Chinese. For a detailed study on this subject, see Charles Coppel 
as different from both the Dutch and the indigenous population. Understandab1y, therefore, the indigenous political movements in the proto-nationalist phase had a tendency to exclude the local Chinese from the very beginning.

The Budi Utomo, primarily a Javanese organization, did not admit Chinese members. The Sarekat Islam (SI) grew out of an association formed by Muslim merchants in 1912 to protect their business interests against Chinese competition. Once organized as a political party, its aims became less emphatically anti-Chinese, and it succeeded in drawing support from a variety of predominantly Islamic ethnic groups in Java, Sumatra and Sulawesi. However, it never had much appeal for the peranakan Chinese, partly because very few peranakan Chinese were Muslims and partly because many such Chinese were attracted to Chinese nationalism.

The Indische Partij of 1912, with its goal of an Indies nation conceived in political terms, tried to gather a following on a multiracial basis. But it was primarily a Eurasian party, and its ideas were not shared by the majority of Indonesian proto-nationalists. Again, the peranakan Chinese were not attracted.

The Indische Sociaal Democratische Vereeniging (ISDV, 1914), like the Indische Partij, sought to organize across racial lines, but it only appealed to a very tiny number of the peranakan Chinese. This was partly because the peranakan Chinese in Java were mainly traders and artisans, hence unattracted to the ISDV's radical program, and partly again because of the prevalence of Chinese nationalism.

After the ISDV became the Indonesian Communist Party (Partai Komunis Indonesia, PKI) it tried to secure support from local Chinese, ${ }^{5}$ particularly laborers. With regard to the totok, the attempt proved fruitless owing to a language barrier and the totok's strong orientation towards China. There was no language barrier between the PKI leaders and peranakan Chinese, but the number of the latter who became members of the party was apparently quite small. Though no exact membership figures are available, there were only eight peranakan Chinese among the 823 party activists exiled to Boven Digul after the 1927 rebellions. ${ }^{6}$ The reasons given for the failure of the

and Leo Suryadinata, "The Use of the Terms Tjina and Tionghoa in Indonesia: An Historical Survey," in Papers on Far Eastern History, No. 2 (September 1970), pp. 97-118.

5. Ruth McVey, The Rise of Indonesian Communism (Ithaca: Cornel1 University press, 1965), pp. 225-229.

6. Two prominent peranakan Chinese in the PKI were Kho Tjun Wan (Semarang) and Tan Ping Tjiat (Surabaja). McVey, Rise of Indonesian Communism, p. 266; Tan Hong Boen, Orang-Orang Tionghoa Jang Terkemoeka di Java (So1o, n.p., 1935?), pp. 28 and 115. Kho Tjun Wan (Kho Tjoen Gwan) was born in Brebes, had no formal education and got involved in the Indies revolutionary movements. He was at one time the director of Sinar Hindia, a newspaper affiliated with Sarekat Islam. He became a Communist and was detained by the colonial authorities after the 1926-1927 rebellion. He was soon released and moved to Kudus. Tan Ping Tjiat, like Kho, had no formal education. He was born in Surabaja where he became a 
ISDV to draw many peranakan Chinese into the movement appear to apply also to the PKI. Ruth McVey has stated that, while a few peranakan joined, the majority of local Chinese (both totok and peranakan) preferred to stay out of Indonesian politics and "especially out of a movement that offered many prospects for trouble and almost none for success."7

During the proto-nationalist phase, the relationship between the indigenous people and local Chinese in Java was not cordial. The Chinese were-popularly stereotyped as money-lenders and merchants both by native Indonesians and by the Dutch authorities. In the eyes of both, the Chinese tended to be seen as a rich and conservative group standing in the way of native advancement. The Dutch Ethical Policy introduced at the beginning of the century included a number of measures clearly intended to protect the indigneous populaagainst the Chinese; to the local Chinese, these measures seemed devised to promote the advancement of the native population at their expense. ${ }^{8}$ Anti-Chinese riots took place in 1912 and $1918 .{ }^{9}$ The 1912 riots in Surakarta and Surabaja were believed to be connected with the activities of the SI though the SI leadership was not held directly responsible. The 1918 riot in Kudus was a manifestation of a conflict of interests between local Chinese businessmen and the indigenous merchants. A few Chinese were killed and many were injured. Many Chinese houses in Kudus Tua were burned down. The prejudices of the two racial groups were clearly reflected in their public responses towards the Kudus incident. The peranakan Chinese press blamed the native population and the indigenous press took the same hostile attitude towards the Chinese. Even Semaun, the leftist leader of the SI, admitted that deep racial antipathies existed between the two groups. He wrote in the SI's newspaper as follows:

Nowadays the 1 ife of the natives is worsening; they feel that they are getting poorer and poorer but they

member of the PKI and got involved in the rebellion. He was not exiled to Boven Digul. He later became a member of the Chung Hwa Hui, a right-wing peranakan Chinese party formed in 1928. Among the eight Chinese exiled to Boven Digul, six were from Blora and Tjepu, one from Tumpang and one from Malang. Al1 were identified as PKI officers, including the chairman of the Blora and $T j e p u$ branches. As to their occupations, five were "traders," two were unemployed and one was a cake-maker. See Keng Po, March 16, 1927, cited by Mary F. A. Somers, "Peranakan Chinese Politics in Indonesia" (Ph.D. dissertation, Cornell University, 1965), p. 91; Sin Po, June 10,1927 .

7. McVey, Rise of Indonesian Communism, p. 229.

8. Lea E. Williams, Overseas Chinese Nationalism, pp. 38-41; A. Cabaton, Java, Sumatra and Other Islands of the Dutch East Indies (New York: Scribner's, 1911), pp. 154-166.

9. George McT. Kahin, Nationalism and Revolution in Indonesia (Ithaca: Corne11 University Press, 1952), p. 67. For a fuller account of the Kudus incident see The Siauw Giap, "Group Conflict in a Plural Society," Revue du Sudest Asiatique, 1 (1966), pp. 20-31. 
can see for themselves that other peoples [bangsa], [particularly] the Chinese, are getting richer. [The Chinese] show off their wealth and contrast it with the poverty of the natives... .

The contrast between the poverty of the natives and the richness of the other peoples caused the hatred of these natives toward the rich, of whom a large number are the Chinese. The hatred of the poor natives towards their rich fellow natives disappeared because they belong to the same race and same religion. What is left is only their hatred towards the rich Dutch and the rich Chinese. The hatred towards the rich Dutch is drowned because the Dutch are the rulers and they are very strong, but the hatred towards the rich Chinese has no counterbalance. . . . ${ }^{10}$

Semaun's remarks reveal the extent to which the indigenous peoples were hostile to the local Chinese, both for being economically stronger and for being alien. They also show that the word bangsa already had a racial connotation.

The Peranakan Chinese and Indonesian

Nationalism

The Indonesian nationalism that came into being after the Communist rebeliions and the formation of the Partai Nasional Indonesia (PNI, Nationalist Party) marked the beginning of a new phase in modern Indonesian history. But one major feature of the protonationalist phase continued to exist in the ideas of the PNI, namely a racial concept of the Indonesian nation. Article 4 of the PNI's constitution stated clearly that "the persons eligible for membership in this party are native Indonesians (orang-orang bangsa Indonesia) ${ }^{1}$ not less than eighteen years old; other Asians (orangorang bangsa Asia jang lain) can be associate members."l2

Two instances can be cited to show that the leaders of the PNI during its formative stage did not consider the peranakan as Indonesians. Prior to the PNI's inception, Dr. Tjipto Mangunkusumo, a member of the preparatory committee, proposed that peranakan (in this case Eurasians) should be allowed to be members of the Central Committee. His proposal was rejected and this caused him not to join the PNI. ${ }^{13}$

10. The article was originally published in 0etoesan Hindia. It is cited in "Peroesoehan di Koedoes dan Hal HaI Jang Berhoeboengan Dengen Itoe III," Sin Po, November 15, 1918.

11. Orang has a meaning similar to bangsa and is loosely used to refer to people, person, race, ethnic group, etc.

12. Soeloeh Ra'jat Indonesia, April 11, 1928, p. 205.

13. M. Balfas, Dr. Tjipto Mangoenkoesoemo, Demokrat Sedjati (Djakarta: Djambatan, 1952), p. 101 . 
Another example was the case of Kwee Tjing Hong, a peranakan Chinese who owned a bookshop in Palembang and had taken the initiative in setting up a local branch of the PNI. The founding meeting had even been held in his own home. Since he was a peranakan and was considered by other Indonesian members as a Chinese, he could only become an associate member according to the PNI's constitution. He was nevertheless active in the PNI and tried to set up another branch in Bangka, though without success. When the PNI's leaders were arrested by the Dutch authorities, Kwee was also detained but was soon released. Looking back later, Kwee felt bitter that his nonindigenous status had barred him from holding any executive position in the branch which he himself had formed. He eventually left the PNI because he said that his fellow party members regarded him as a Chinese and hence an alien, no matter how much he tried to be an Indonesier (Dutch term for an Indonesian). ${ }^{14}$

It is probably true that on $1 y$ a few peranakan individuals attempted to join the PNI. The majority remained imbued with Chinese nationa1sim or confined their concerns to their own limited group interests, and were indifferent to the Indonesian nationalist movement. At the same time, the Indonesian nationalists made no attempt to include local Chinese in their parties. The reasons for this are many, but racial tendencies in the movement were certainly important. Paradoxically, the contemporary rise of Pan-Asian ideas also accentuated the separation between the Chinese and the indigenous Indonesians. Pan-Asianism spread widely both among the secular Indonesian nationalists and among the Indies Chinese nationalists in the late twenties and early thirties. Members of both groups saw themselves as Asians and therefore as having a common goal--to drive the Western Powers out of Asia. Yet, ironically, these ideas helped to perpetuate the separation of the two groups since they envisaged an alliance rather than a fusion between them. At bottom, each nation was primarily concerned with itself, and this concern ultimately caused some secular nationalists in Indonesia to redefine Pan-Asianism as InterAsianism. This point will be discussed later.

In the early thirties, peranakan Chinese leaders such as Liem Koen Hian and Ko Kwat Tiong, who formed the Partai Tionghoa Indonesia (PTI, Indonesian Chinese Party) in 1932,15 came to believe that the peranakan Chinese should become Indonesier in the political sense; they should not only regard Indonesia as their homeland but also side with the indigenous Indonesians in their struggle for the independence of Indonesia. Liem Koen Hian's concept of an Indonesier was derived from the ideas of the Indische Partij (1ater Insulinde), which in turn were influenced by the thinking of Dr. Tjipto Mangunkusumo.

Dr. Tjipto formulated his idea of an Indies Nation (Indische Natie) as early as 1917. He believed that the future Indies nation

14. The experience of Kwee Tjing Hong was first published in Sin Po and republished in Djawa Tengah Review, August 1934, p. 617 .

15. The PTI was formed on September 23, 1932, in Surabaja. Its aims were "to help Indonesia economically, socially and politically towards a state where all people enjoy equal rights and obligations." Sin Tit Po, September 26, 1932. Liem, a journalist, was the founder of the PTI Surabaja branch, while Ko, a lawyer, was the founder of the PTI Semarang branch. 
should be composed of all who considered the Indies their motherland and actively helped to develop it. Those who placed the interest of a foreign country above the Indies could not be called Indies nationals. Dutch Eurasians, peranakan Arabs and peranakan Chinese were al1 considered constituent parts of the Indies nation. ${ }^{16}$ Liem claimed to be an Indonesier in this sense. He did not use the term bangsa Indonesia, probably because he was aware of its racial connotations.

In the 1930's, Liem's concept was not shared by any major group of Indonesian nationalists, secular or Muslim. Even the internationally-minded socialist intellectual sutan Sjahrir, writing in the 1930 's, used the terms Indonesische Volk (Indonesian people) and Indonesier to refer to the indigenous Indonesians, excluding nonindigenous groups. ${ }^{17}$ Nevertheless, a handful of Indonesian secular nationalists, strongly influenced by Marxism, began to develop a non-racial concept of an Indonesian nation in the mid-thirties. This group, which included Sanusi Panê, Muhammad Yamin and Amir Sjarifuddin, published a newspaper called Kebangoenan, ${ }^{18}$ and 1ater formed a political party, the Gerakan Rakjat Indonesia (or Gerindo, Indonesian Peoples Movement) to propagate their ideas.

Sanusi, for example, in discussing the concepts of race, nation and state, argued that racial concepts were indefensible because no race (ras) was pure; there were only two concepts with a basis in reality, namely nation (natie) and state, neither of which had anything to do with race. ${ }^{19}$ To Sanusi, a nation was a cultural concept and had to do with a sense of belonging, while a state was a political unit intended to safeguard the interests of its nationals. The peranakan, he said, were a constituent element of the Indonesian nation. Many peranakan were still uninterested in the Indonesian nation because they had not yet been awakened, but those who were conscious of Indonesian nationhood deserved to be called Indonesians (orana Indonesia). Sanusi carefully used the term orang Indonesia rather than bangsa Indonesia. He also chose the term natie instead of bangsa to emphasize that his concept of an Indonesian nation was non-racial.

Whereas the concept of Pan-Asianism had been popular in the late twenties and early thirties, the idea of Inter-Asianism or Antara Asia was introduced in the mid-thirties by some secular Indonesian nationalists to overcome the ambiguity of the term Pan-Asianism. The Kebangoenan group was the main propagator of this idea. They explained that Inter-Asianism was different from Pan-Asianism. Whereas the Pan-Asianists claimed that the interests of Asia should be put first (despite often acting in a manner contrary to this), the Kebangoenan

16. Balfas, Mangoenkoesoemo, pp. 75-82.

17. Sjahrazad (Sutan Sjahrir), Indonesische Overpeinzingen (Amsterdam: De Bezige Bij, 1950), pp. 62, 72,93,113 and 149.

18. Kebangoenan began publication on June 5, 1935. Its first editor-in-chief was Sanusi Pané, its director was Muhammad Yamin, and among its regular contributors were Amir Sjarifuddin and Liem Koen Hian.

19. Peranakan," Koebangoenan, August 18, 1936. 
group declared that the interests of Indonesia should be supreme and stated their unconditional adherence to Indonesian nationalism (Kebangsaan Indonesia), though they admitted that the problem of Indonesian nationalism was part of the Asian problem. ${ }^{20}$

But apart from this tiny intellectual minority, most indigenous Indonesians still did not accept a non-racial concept of the Indonesian nation. The debate between Dr. Sutomo and Liem Koen Hian in 1936 is instructive on this point.

In $1936 \mathrm{Dr}$. Sutomo went to Japan on a study tour. After returning to Java he wrote a series of articles on his impressions of the journey. They were published in Soeara oemoem, a party newspaper of the Parindra. ${ }^{21}$ Dr. Sutomo described the progress of Japan and expressed his admiration of this Asian country. He even argued that the Japanese had originated from Indonesia.

Liem criticized Dr. Sutomo in Sin Tit Po. ${ }^{2}$ He said that Dr. Sutomo, though a national leader, wrote like a journalist and a tourist. His view of Japan was superficial because he only described what he liked and had failed to account for the aggressive policy of Japan towards the rest of Asia. He had not explained the basic structure of Japanese society--especially its economic and political features. According to Liem, Japan had reached the stage of mature capitalism, and hence had become an imperialist power.

Dr. Sutomo rejected these criticisms. He wrote in Soeara Oemoem that Liem was a Chinese who had strong feelings against Japan because Japan attacked China. He teased Liem, saying, "Don't become uncontrolled in your hatred of Japan and don't let your emotion speak if you really want China to be freed from the grasp of a small but strong Japan." 23

Liem replied that as an Indonesian of Chinese descent he did not hate Japan. On the contrary, he felt grateful to Japan because her actions had awakened China. He added that he was writing not as an ethnic Chinese but "as a son of Indonesia who is as Indonesian as Dr. Sutomo." He expressed his regret that Dr. Sutomo had become "a propagandist of Japanese imperialism." 24

A number of indigenous Indonesians appeared to defend Dr. Sutomo in newspapers such as Soeara Oemoem and Pewarta Deli. They shared the view that Japan was an admirable country and attacked Liem for insulting Dr. Sutomo and "confusing" the Indonesian nationalist movement. They concluded that Liem's attitude was not the attitude of an Indonesian.

20. Kebangoenan, June 5-6, 1936 .

21. Kebangoenan, Ju1y 10, 1936.

22. Kebangoenan, Ju1y 27, 1936.

23. Cited in Sin Tit Po, September 4, 1936.

24. Sin Tit Po, July 27, 1936. 
The criticisms of Liem were quite personal, and Liem replied in kind. The debate became confused and soon departed from the original issue. But all along Liem was defended by $\mathrm{Dr}$. Tjipto and Sanusi. Dr. Tjipto did not accuse Dr. Sutomo of being a propagandist for Japanese imperialism, but he shared Liem's views on the defects of Dr. Sutomo's writing. ${ }^{2}$ Sanusi pub1ished an artic1e in Kebangoenan in which he deplored the fact that Dr. Sutomo's defenders were "no longer discussing the original issues but were on very personal things."26 Analyzing the issues of the debate, he criticized Dr. Sutomo for not describing Japan as an imperialist country, but also criticized Liem for not mentioning the difficulties which Japan had encountered in resisting Western imperialism. Nevertheless, he showed his sympathy for Liem by rejecting the accusations made by his opponents that Liem had insulted $\mathrm{Dr}$. Sutomo. To the charge that Liem's‘blunt remarks were inconsistent with the gentleness of the Indonesian morality (susiza Indonesia), Sanusi replied that:

Liem showed his toughness, firmness and skill in debate. . . . Is that not allowed by Indonesian morality? Was this not the character of Wrekodara whom the [Dr. Sutomo's] defenders admire? Was Wrekodara not militant and skilful? After all, it was only he who could finally succeed in getting the Tirtapawitra, as is related in the story of Dewa Rutji. And Soekarno, with his firmness, is he not an Indonesian according to the Indonesian morality of these writers? ${ }^{27}$

Sanusi also denied that Liem was not an Indonesian. "We consider Mr. Liem as a man who is conscious of Indonesia's interests, and hence we regard him as an Indonesian (orang Indonesia)."

In mid-September, Dr. Tjipto wrote a letter to the editor of Kebangoenan in connection with the debate. ${ }^{28}$ He argued that as an Asian country, Japan had enhanced the prestige of Asia by its achievements in many fields. In pointing this out, Dr. Sutomo had performed a valuable service. Nonetheless, Indonesians should not be blinded by these achievements. They should be very cautious of Japanese imperialism. He expressed his view that Dr. Sutomo had written his articles as a tourist who did not realize the problems confronting Japan. Finally he asserted that "Liem Koen Hian is an Indonesier, with or without pitji." For "Indonesierschap is a

25. Sin Tit Po, August 22, 1936.

26. August 19, 1936, republished in Sin Tit Po, August 22, 1936.

27. Wrekodara (or Bima) is the hero of the story of Dewa Rutji, one of the best known of the wajang stories. He overcame a multitude of obstacles before final1y obtaining the secret of Immortality (Tirtapawitra--in Sanusi's article it is called Amerta). For the full story of Dewa Rutji see A. Seno Sastroamidjojo, Tjeritera Dewa Rutji (Dengan Arti Filsafatnja) (Djakarta: Kinta, 1962).

28. The letter, written in Dutch, was published on September 19, 1936. An Indonesian translation appeared on September 21, 1936. Sin Tit Po republished the translation on September $22,1936$. 
political concept."29 He castigated some writers in the debate, stressing that no one had the right to turn the debate into a fight between the Chinese and the native people. With the appearance of Dr. Tjipto's long letter, the debate came to an end.

The Peranakan Chinese and the Parindra, The Gerindo and the Gapi

The course of the debate showed that the whole indigenous press, except for Kebangoenan, which was in the hands of radical Indonesian nationalists influenced by Marxism, was against Liem, and that this opposition often originated from prejudice and distrust towards the Chinese. Nonetheless, the debate itself and the contemporary activities of peranakan in Indonesian political life seem to have resulted in a slow shift in attitudes. The cooperative party Parindra, which became influential after the suppression of the radical nationalist parties in the early thirties, began to consider the question of whether it would open its membership to the peranakan. A motion to permit admission was initiated at the 1937 congress, but discussion was postponed until the next congress. Husni Thamrin was asked to prepare a paper on which the discussion would be based.

At the 1938 congress, Thamrin read his paper ${ }^{30}$ which expressed the view that the Parindra should not open its membership to any type of peranakan for the time being. Thamrin said that the Eurasian peranakan were legally assimilated to European status and hence enjoyed more privileges than the indigenous Indonesians. For this reason they were unlikely to be regarded with favor by the latter. Moreover, the attitude of their leaders did not convince him that they really wanted to become Indonesians. As to the peranakan Chinese, though they had assimilated to indigenous status, they were in a socially and economically superior position to the indigenous Indonesians. He did not deny that the peranakan Chinese in the Partai Tionghoa Indonesia (PTI) were Indonesia-oriented and considered Indonesia as their motherland ( $\left.\tan a h_{-}-a i r\right)$, but they still wanted to maintain their customs and their Chinese education. He understood that the PTI was working for Indonesia and that its members wanted to have the same legal status as the indigenous Indonesians, nonetheless they still wanted to remain culturally Chinese. With regard to the Arab peranakan, Thamrin noted that the Partai Arab Indonesia (PAI) had a political program roughly similar to that of the PTI. However, since this group was Muslim, it would be easier to assimilate it into the indigenous community. He was not sure about the peranakan Indian organization and assumed that it resembled the PTI and the PAI.

29. The original text is, "Liem Koen Hian is Indonesier. Met of zonder pitji. . . omdat indonesierschap is een politiek begrip." The translation given by Kebangoenan is "LKH orang Indonesier. Dengen atau tanpa pitji. karena keindonesiaan jalah faham politiek." Pitji (or petji) is a type of black velvet cap worn by indigenous Indonesians.

30. "Sikap Parindra Terhadap Kaoem Indo," Mata Hari, January 7, 1939 . 
After giving this overview of the various peranakan parties, Thamrin concluded that to his mind the Parindra was based on an Indonesianism (Keindonesiaan) which aimed at uniting various racial groups (bangsa) who were not Indonesians but shared similar ideas, destiny and education with Indonesians. Thamrin's idea of an Indonesian nation was a cultural concept, but it was not without racial overtones. He wanted an indigenous Indonesian culture into which the peranakan would be absorbed.

He argued further that since the Indonesian nationalists themselves were still very divided in their outlook, for the time being acceptance of peranakan would only cause more internal confusion. In any case, he believed the peranakan movement was still flourishing; thus, even if the Parindra opened its membership to peranakan, few would care to join. These considerations caused him to urge Parindra to work with the peranakan parties but not open its door to individual peranakan.

Thamrin's proposal was accepted by the Congress. It did not arouse much overt reaction in the peranakan Chinese community. Evidently, not many Chinese were really interested in joining the Parindra.

Almost a year after the Parindra accepted Tharmin's conservative proposal, the nationalist party Gerindo opened its membership to peranakan. As a left-wing party, the Gerindo was internationallyoriented. It believed that the iiberation of Indonesia would largely depend on the international situation, and it allowed the members to cooperate with the colonial authorities on the grounds that the threat of Fascism was greater than that of colonialism.

At the Gerindo's Palembang congress Amir Sjarifuddin justified the party opening its doors to the peranakan on the grounds that they represented a reality that the Indonesian nationalists must face. There were now more and more peranakan interested in joining the Indonesian nationalist movement, and hence the door should be opened to them. ${ }^{31}$

Amir then gave the Gerindo's definition of nationality (kebangsaan). He said the nationality of a person was not decided by blood or skin or shape of face but by three factors: goal, destiny and desire. People who had the same goal, the same destiny and the same desire belonged to one nation (bangsa). He gave the examples of Switzerland and the United States as instances of nations whose citizens had not originated from one race.

The decision of the Gerindo to accept peranakan as ful1 members caused various reactions. The PAI and the PTI welcomed the decision and Liem Koen Hian even left the PTI to join the Gerindo. ${ }^{32}$ But many indigenous Indonesians were still doubtful of the sincerity of peranakan wishes to become Indonesian. ${ }^{3}$ One indigenous newspaper,

31. "Rapat Oemoem Congres Gerindo ke II di Sriwidjaja, II (Penoetoep)," Pemandangan, August 2, 1939; see also Sin Tit Po, August 2, 1939.

32. Sin Tit Po, August 4, 1939 ; January 2, 1940.

33. Sin Tit Po, August 2, 1939. 
Sinar Dezi, expressed doubts about the peranakan but agreed to accept them if they really felt that they shared the same aim of life, the same destiny and the same future as the indigenous Indonesians." Another newspaper, Tjaja Timoer, suggested that the PTI and the PAI, now based on ethnic groups, should dissolve themselves and that their members join the Indonesian parties. ${ }^{35}$ The PAI and the PTI in reply argued that the Gerindo would not accept every peranakan who wanted to become a member. Since the separateness of various ethnic groups was still a reality, the PTI and the PAI were, therefore, still useful as a "melting pot." 36

Later, under the shadow of the Japanese invasion, the Indonesian nationalist parties formed a combined political force called the Gabungan Politiek Indonesia (Gapi, Indonesian Political Union). The PTI and the PAI supported the Gapi movement and attempted to $j o i n$ it but were offered on $1 y$ associate memberships. The PAI joined on this basis but the PTI stayed outside. As a result, a newspaper called Berita oemoem criticized the PTI for being opportunistic. The PTI replied that, "The PTI is ready to take the responsibilities and consequences as a ful1 member of the Gapi but it does not want to be an associate member. . . because it does not wish to become a stepson of an Indonesian mother." 37

The Peranakan Chinese and the "Illegal PKI"

Brief mention must be made of the role of the peranakan Chinese in the "Illegal PKI." After the PKI was declared illegal by the colonial authorities in the wake of the 1926-1927 uprisings, the party went underground. In spite of this, it managed to recruit a number of discontented peranankan Chinese who were attracted by its radical and non-racial approach.

If there were no well-educated peranakan in the PKI during the proto-nationalist phase, ${ }^{3} 8$ in the nationalist period, quite a few peranakan Chinese intellectuals joined the party. These peranakan intellectuals mostly came from well-to-do families. Some of them such as Tan Ling $\mathrm{Dj}$ ie and Tjoa Sik Ien received tertiary education in Europe where they were exposed to Communism and became involved in the international Communist movement. ${ }^{39}$ Others were educated in local Dutch secondary schools, but were also exposed to Communist ideology. The most prominent members of this group were Oei Gee Hwat and Siauw Giok Tjhan. These peranakan Chinese intellectuals

34. Sin Tit Po, August 15, 1939.

35. Tjaha Timoer, August 5, 1939 , cited by Sin Tit Po, August 8, 1939.

36. Sin Tit Po, August 8-9, 1939 .

37. Sin Tit Po, March 39, 1941.

38. See note 6 .

39. Tan Ling Djie studied in a law school while Tjoa Sik Ien graduated from a medical school. 
were particularly active after 1935, when the Comintern decided to carry out a popular front policy against Fascism.

The peranakan intellectuals who were associated with the "Illegal PKI" tried to infiltrate various non-Communist organizations. But they faced great difficulties in getting into those organizations which were still limited to indigenous membership. (Until 1939, only one indigenous party, the Gerindo, opened its membership to peranakan.) Under such circumstances, they were forced to function with in racially defined limi.ts though they worked to cooperate with sympathetic Indonesian nationalist parties in the struggle to fight Fascism.

The PTI, which was basically a leftist party anyway, gradually fell into the hands of these intellectuals. Dr. Tjoa Sik Ien succeeded in obtaining the presidency of the PTI 40 in the late thirties. He also became the director of $\operatorname{Sin} T i t$ PO, ${ }^{41}$ a semi-official mouthpiece of the PTI. Tan Ling Djie became the editor-in-chief of this newspaper in 1939.42 Oei Gee Hwat, who worked for a time at Sin Tit Po and taught at the PTI School, ${ }^{3}$ left Sin Tit Po towards the end of 1930 's and attached himself to the Pewarta Soerabaia, a peranakan Chinese newspaper which held moderate Chinese nationalist views. ${ }^{4}$ Siauw Giok Tjhan, who was also a radical member of the PTI, worked for Mata Hari, ${ }^{45}$ a Semarang-based peranakan Chinese newspaper which was supported by a big Chinese business firm.

Under the influence of Tjoa Sik Ien, the PTI cooperated closely with the Gerindo and the PAI, ${ }^{46}$ but failed to draw mass support from the peranakan Chinese. As a matter of fact, by the end of the thirties, the PTI was still mainly an East Java based party with only a few hundred members.

Conclusion

From this brief survey of the historical relationship between the Indonesian nationalist movement and the peranakan Chinese, the following conclusion can be drawn. The Indonesian nationalist movement had a tendency to exclude the peranakan Chinese and an attempt to include this group made by the Communists and other left-wing parties did not have much success. On the peranakan Chinese side, the communal feelings were still strong, and though the PTI identified itself with the Indonesian nationalist movement, it remained, in fact, a peranakan Chinese party and hence, not yet an Indonesian party.

40. Sin Tit Po, November $20,1939$.

41. Sin Tit Po, January 15, 1938 .

42. Sin Tit Po, December 16, 1939.

43. Sin Tit Po, August 17, 1938.

44. Interview with Tio Ie Soei, former editor of Pewarta Soerabaia.

45. Interview with Tjoa Tjie Liang, former secretary of the PTI and member of the editorial board of Mata Hari.

46. Sin Tit Po, January $17,1939$. 